\title{
Entrapped Single Tungstate Site in Zeolite for Cooperative Catalysis of Olefin Metathesis with Brønsted Acid Site
}

\author{
Pu Zhao ${ }^{1 \dagger}$, Lin $\mathrm{Ye}^{1 \dagger}$, Zhenyu Sun ${ }^{1 \ddagger}$, Benedict T. W. Lo ${ }^{1}$, Harry Woodcock ${ }^{1}$, Chen Huang ${ }^{2}$, Chiu \\ Tang3, Angus I. Kirkland ${ }^{2,3}$, Donghai Mei ${ }^{4}$ and Shik Chi Edman Tsang ${ }^{{ }^{*}}$ \\ ${ }^{1}$ Wolfson Catalysis Centre, Department of Chemistry, University of Oxford, Oxford, OX1 3QR, UK. \\ ${ }^{2}$ Department of Materials, University of Oxford, Oxford, OX ${ }_{13} \mathrm{PH}, \mathrm{UK}$. \\ ${ }^{3}$ Diamond Light Source Ltd, Harwell Science and Innovation Campus, Didcot, OXı1 oDE, UK. \\ ${ }^{4}$ Physical and Computational Sciences Directorate \& Institute for Integrated Catalysis, Pacific Northwest National \\ Laboratory, Richland, WA, PO Box 999, USA.
}

\begin{abstract}
Industrial olefin metathesis catalysts generally suffer from low reaction rates and require harsh reaction conditions for moderate activities. This is due to their inability to prevent metathesis active sites (MAS) from aggregation and their intrinsic poor adsorption and activation of olefin molecules. Here, isolated tungstate species as single molecular MAS is immobilized inside zeolite pores by Brønsted acid sites (BAS) on the inner surface. It is demonstrated that unoccupied BAS in atomic proximity to MAS enhance olefin adsorption and facilitate the formation of metallocycle intermediates in a stereospecific manner. Thus, effective cooperative catalysis takes place over the BAS-MAS pair inside the zeolite cavity. In consequence, for the cross-metathesis of ethene and trans-2-butene to propene, under mild reaction conditions, the propene production rate over $\mathrm{WO}_{\mathrm{x}} / \mathrm{USY}$ is ca. 7,300 times that over the industrial $\mathrm{WO}_{3} / \mathrm{SiO}_{2}$ based catalyst. A propene yield up to $79 \%$ (8o\% selectivity) without observable deactivation was obtained over $\mathrm{WO}_{\mathrm{x}} / \mathrm{USY}$ for a wide range of reaction conditions.
\end{abstract}

\section{INTRODUCTION}

Olefins are essential feedstocks for the production of many petrochemicals, oleochemicals, polymers and specialty chemicals. Catalytic olefin metathesis is an important reaction in the chemical industry. For example, the cross-metathesis of ethene and 2-butene to propene and the reverse reaction play a significant role in buffering the global supply of ethene and propene. Over the past fifty years, a number of metal oxides including $\mathrm{Re}_{2} \mathrm{O}_{7}$, $\mathrm{MoO}_{3}$ and $\mathrm{WO}_{3}$ supported on $\mathrm{SiO}_{2}$ and/or $\mathrm{Al}_{2} \mathrm{O}_{3}$ have been found to be effective as olefin metathesis catalysts under continuous flow conditions. ${ }^{1}$ For various reasons, an inexpensive and robust $\mathrm{WO}_{3} / \mathrm{SiO}_{2}$ based material is the only widely-employed catalyst in the industry for the cross-metathesis of ethene and 2-butene to propene and the reverse reaction. High temperature $\left(300-550^{\circ} \mathrm{C}\right)$ and high pressure ( $>20$ bar) are required for moderate activities to meet the industrial requirement., ${ }^{1,2}$ Active site isolation shifting from $\mathrm{WO}_{3}$ nanocrystals to surface polymeric $\mathrm{WO}_{\mathrm{x}}$ and ultimately to isolated $\mathrm{WO}_{\mathrm{x}}$ was found to be promising in improving catalytic activity. ${ }^{3}$ Considerable efforts have been made on immobilizing isolated organometallic complexes on $\mathrm{SiO}_{2}$ and/or $\mathrm{Al}_{2} \mathrm{O}_{3}$ for high activities despite the fact that they tend to aggregate on open surfaces. ${ }^{4-6}$ Nonetheless, the industrial application of these catalysts requires further development. Another way to improve the activity of industrial $\mathrm{WO}_{3} / \mathrm{SiO}_{2}$ based catalyst becomes clear when one studies the fundamental olefin metathesis reaction mechanism. It is generally accepted that olefin metathesis proceeds via metallocycle intermediates in the rate-determining steps (Scheme 1). ${ }^{1,7,8}$ The efficient formation of metallocycle intermediates requires fast adsorption of olefin molecules and appropriate alignment between the $\mathrm{C}=\mathrm{C}$ bond of adsorbed olefin molecules and the $\mathrm{W}=\mathrm{O} / \mathrm{W}=\mathrm{C}$ bond of metathesis active sites (MAS) for $[2+2]$ cycloaddition. ${ }^{7,9,10}$ This may be difficult to achieve with a catalyst that contains only isolated MAS. There is an indication from previous studies that the introduction of acidic sites to olefin metathesis catalysts can increase the rate of olefin metathesis reaction. ${ }^{11}$ Thus, enhanced activity is obtained when supported $\mathrm{WO}_{3}$ or $\mathrm{MoO}_{3}$ is blended with zeolites. ${ }^{12,13}$ However, the ill-defined interface between bulk acidic zeolite and MAS do not lead to significant rate enhancement, indicating the cooperative catalysis is not yet optimized.

Thus we designed a new type of bifunctional olefin metathesis catalysts by placing an isolated tungstate as $\mathrm{WO}_{\mathrm{x}}$ MAS in a zeolite cavity where unoccupied Brønsted acid sites (BAS) are in atomic proximity for efficient cooperative catalysis. As a result, we show for the first time that, at $200^{\circ} \mathrm{C}$ and 1 bar, the propene production rate over $\mathrm{WO}_{\mathrm{x}} / \mathrm{USY}$ is ca. 7,300 times that over the industrial $\mathrm{WO}_{3} / \mathrm{SiO}_{2}$ based catalyst. A propene yield up to $79 \%$ with $80 \%$ selectivity without observable deactivation can be 
achieved over $\mathrm{WO}_{\mathrm{x}} / \mathrm{USY}$ for a wide range of reaction conditions. The structure of $\mathrm{WO}_{\mathrm{x}} / \mathrm{USY}$ catalyst was elucidated by synchrotron X-ray powder diffraction (SXRD) and Rietveld refinement, supported by aberration-corrected scanning transmission electron microscopy (STEM), extended X-ray absorption fine structure (EXAFS) spectroscopy, and so on. These characterization results and density functional theory (DFT) calculation suggest that olefin adsorption can be enhanced by unoccupied BAS and the formation of metallocycle intermediates over isolated $W_{\mathrm{x}}$ MAS can be greatly facilitated by the nearby unoccupied BAS through the appropriate alignment between the $\mathrm{C}=\mathrm{C}$ bond of adsorbed olefin molecules and the $\mathrm{W}=\mathrm{O} / \mathrm{W}=\mathrm{C}$ bond of $\mathrm{WO}_{\mathrm{x}}$ MAS for $[2+2]$ cycloaddition. This accounts for the exceptional olefin metathesis rate observed.

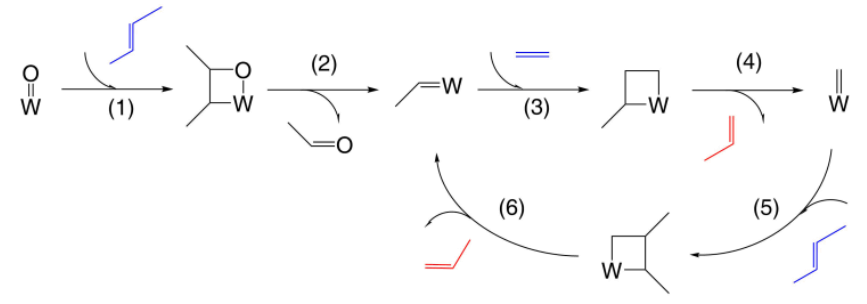

Scheme 1. The reaction mechanism of the crossmetathesis of ethene and trans-2-butene to propene over isolated WO $_{x}$ MAS. ${ }^{1,7}, 8(1,2)$ Pseudo-Wittig initiation mechanism for $\mathrm{W}=\mathrm{CHCH}_{3}$ formation and (3-6) the following metallacyclobutane catalytic cycle to form propene (Chauvin reaction mechanism).

\section{EXPERIMENTS}

Catalyst preparation. $\mathrm{WO}_{3} / \mathrm{SiO}_{2}$ was commercially available. $\mathrm{WO}_{\mathrm{x}} /$ zeolite catalysts $\left(\mathrm{WO}_{\mathrm{x}} / \mathrm{USY}, \mathrm{WO}_{\mathrm{x}} / \mathrm{ZSM}-5\right.$, $\mathrm{WO}_{\mathrm{x}} / \mathrm{SAPO}-11, \mathrm{WO}_{\mathrm{x}} / \mathrm{SAPO}-34$ and $\left.\mathrm{WO}_{\mathrm{x}} / \beta\right)$ were prepared by wet impregnation. USY was obtained from Tosoh. ZSM- 5 and $\beta$ were provided by Sinopec. SAPO-11 and SAPO-34 were purchased from ACS Material. The chemical composition of zeolite supports was analyzed by inductively coupled plasma atomic emission spectroscopy (ICP-AES) or obtained from the literature (Table $\mathrm{S} 1$ ). All zeolites have crystal sizes less than $1 \mu \mathrm{m}$. Other chemicals were purchased from Sigma-Aldrich. Typically, $583 \mathrm{mg}$ ammonia metatungstate hydrate $\left(\left(\mathrm{NH}_{4}\right)_{6} \mathrm{H}_{2} \mathrm{~W}_{12} \mathrm{O}_{40} \cdot \mathrm{xH}_{2} \mathrm{O}\right)$ was dissolved in $20 \mathrm{~mL}$ deionized water before $5 \mathrm{~g}$ zeolite was added to the solution. After $1 \mathrm{~h}$ magnetic stirring, the dispersion was dried in an $80^{\circ} \mathrm{C}$ oven overnight. The resulting powder was ground and calcinated at $550^{\circ} \mathrm{C}$ for $2 \mathrm{~h}$ in air. The heating rate was $1^{\circ} \mathrm{C} \cdot \mathrm{min}^{-1}$. The $\mathrm{W}$ loading of $\mathrm{WO}_{\mathrm{x}} /$ zeolite catalysts was confirmed to be the same as that of $\mathrm{WO}_{3} / \mathrm{SiO}_{2}$ by ICP-AES (Table $\mathrm{S} 2$ ). $\mathrm{Na}^{+}$-poisoned $\mathrm{WO}_{\mathrm{x}} / \mathrm{USY}\left(\mathrm{WO}_{\mathrm{x}} / \mathrm{Na}\right.$-USY) was prepared by a similar wet impregnation method. Typically, $177 \mathrm{mg}$ sodium nitrate $\left(\mathrm{NaNO}_{3}\right)$ was used for $5 \mathrm{~g} \mathrm{WO}_{\mathrm{x}} / \mathrm{USY}$.

Catalytic activity evaluation. The reaction between ethene $\left(\mathrm{C}_{2}=\right)$ and trans-2-butene (trans-2- $\left.\mathrm{C}_{4}=\right)\left(n\left(\mathrm{C}_{2}=\right) /\right.$ $n\left(\right.$ trans-2- $\left.C_{4}=\right)=2 / 1$ ) was carried out in a stainless steel continuous flow reactor $(3 / 8$ in inner diameter and 15 in length). In a typical experiment, $2.1 \mathrm{~g}$ catalyst $(15-20 \mathrm{~cm}$ length) was loaded into the reactor with quartz wool packed at both ends. The catalyst was pretreated with nitrogen $\left(\mathrm{N}_{2}, 16 \mathrm{ml} \cdot \mathrm{min}^{-1}\right)$ at $550^{\circ} \mathrm{C}$ for $1 \mathrm{~h}$. After the reactor cooled down to the reaction temperature, the reactants, $4 \% \mathrm{C}_{2}=/ \mathrm{N}_{2}$ and $2 \%$ trans- $2-\mathrm{C}_{4}=/ \mathrm{N}_{2}$, were introduced (105 $\mathrm{ml} \cdot \mathrm{min}^{-1}$ each, weight hourly space velocity (WHSV) $=0.27 \mathrm{~h}^{-1}$, volume hourly space velocity $(\mathrm{VHSV})=26-35 \mathrm{~h}$ $\left.{ }^{1}\right)$. The flow rates were controlled by Brooks mass flow controllers. The reaction temperature was controlled by a custom-made furnace. The reaction pressure was controlled by a Swagelok back pressure regulator. The products were analyzed online by a Shimadzu GC-2014 gas chromatograph equipped with an SGE BP-1 column (100\% dimethylpolysiloxane, $30 \mathrm{~m}$ length, $0.53 \mathrm{~mm}$ inner diameter, $5.0 \mu \mathrm{m}$ film thickness) and a flame ionization detector. The trans-2- $C_{4}=$ conversion, propene $\left(C_{3}=\right)$ selectivity and carbon balance were calculated as follows:

$$
\begin{aligned}
& \text { Conversion }\left(\text { trans }-2-\mathrm{C}_{4}^{=}\right) \\
& =\frac{n\left(\text { trans }-2-\mathrm{C}_{4}^{=} \text {in feed }\right)-n\left(\text { trans }-2-\mathrm{C}_{4}^{=} \text {remaining }\right)}{n\left(\text { trans }-2-\mathrm{C}_{4}^{=} \text {in feed }\right)} \\
& \text { Selectivity }\left(\mathrm{C}_{3}^{=}\right)=\frac{n\left(\mathrm{C}_{3}^{=}\right)}{n(\text { all products })} \\
& \text { Carbon balance }=\frac{n(\mathrm{C}) \text { in products }}{n(\mathrm{C}) \text { in feed }} \\
& \text { Yield }\left(\mathrm{C}_{3}{ }^{=}\right)=\text {Conversion }\left(\text { trans }-2-\mathrm{C}_{4}=\right) \times \operatorname{Selectivity}\left(\mathrm{C}_{3}{ }^{=}\right) \\
& \quad \times \text { Carbon balance }
\end{aligned}
$$

High-resolution STEM. High-resolution electron microscopy was carried out using an aberration-corrected JEOL ARM20oF. The microscope was operated at $200 \mathrm{kV}$ in high-angle annular dark-field (HAADF)-STEM mode with HAADF detector collection semi-angles from 73 to $236 \mathrm{mrad}$. The convergence semi-angle was $31.48 \mathrm{mrad}$ with probe array sizes of 1024 by 1024 and a dwell time of $0.8 \mu$ s per pixel. The probe current was $11 \mathrm{pA}$.

EXAFS and XANES. The local environment of $W$ atoms in $\mathrm{WO}_{\mathrm{x}} / \mathrm{USY}$ and $\mathrm{WO}_{\mathrm{x}} / \mathrm{ZSM}-5$ was probed by analyzing their $k^{3}$-weighted $\mathrm{W} \mathrm{L}_{3}$-edge EXAFS spectra collected at beamline B18, Diamond Light Source, UK. The energy resolution $(\Delta E / E)$ was $2 \times 10^{-4}$. Fluorescence mode was used. To ascertain data reproducibility, at least two data sets were collected for each sample. W metal was used as a reference to avoid energy shift of the measured EXAFS spectra. Data analysis was performed using IFEFFIT 1 with Horae packages 2 (Athena and Artemis). The amplitude parameter was set as a fixed input parameter to allow the refinement of the coordination number of $\mathrm{W}$. This parameter was obtained from the analysis of the EXAFS spectrum of $\mathrm{W}$ metal. First-shell data analysis was performed under the assumption of single scattering with the errors estimated by an $R$-factor. The oxidation states of $\mathrm{W}$ in $\mathrm{WO}_{\mathrm{x}} / \mathrm{USY}$ samples were evaluated by analyzing their

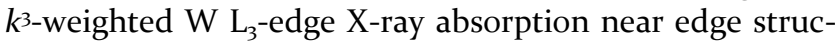
ture (XANES) spectra. These XANES spectra were compared with that of $\left(\mathrm{NH}_{4}\right)_{6} \mathrm{H}_{2} \mathrm{~W}_{12} \mathrm{O}_{40} \cdot \mathrm{xH}_{2} \mathrm{O}$ in which the oxidation state of $\mathrm{W}$ is +6 . 


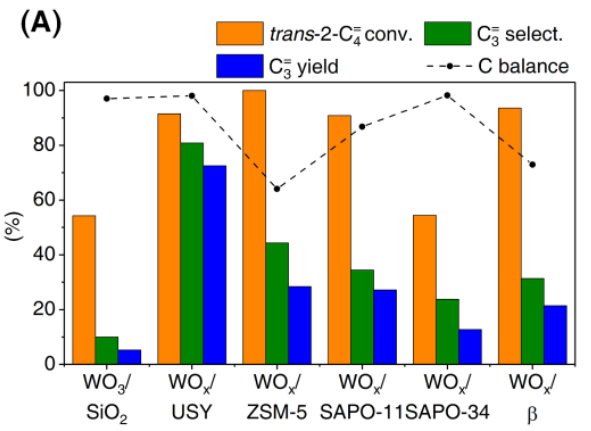

(D)

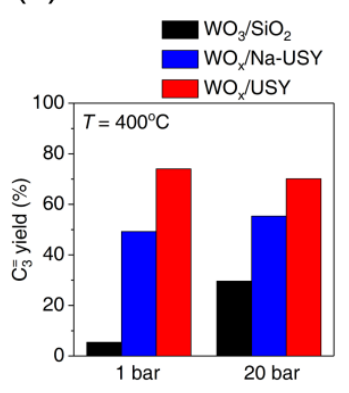

(E)
(B)
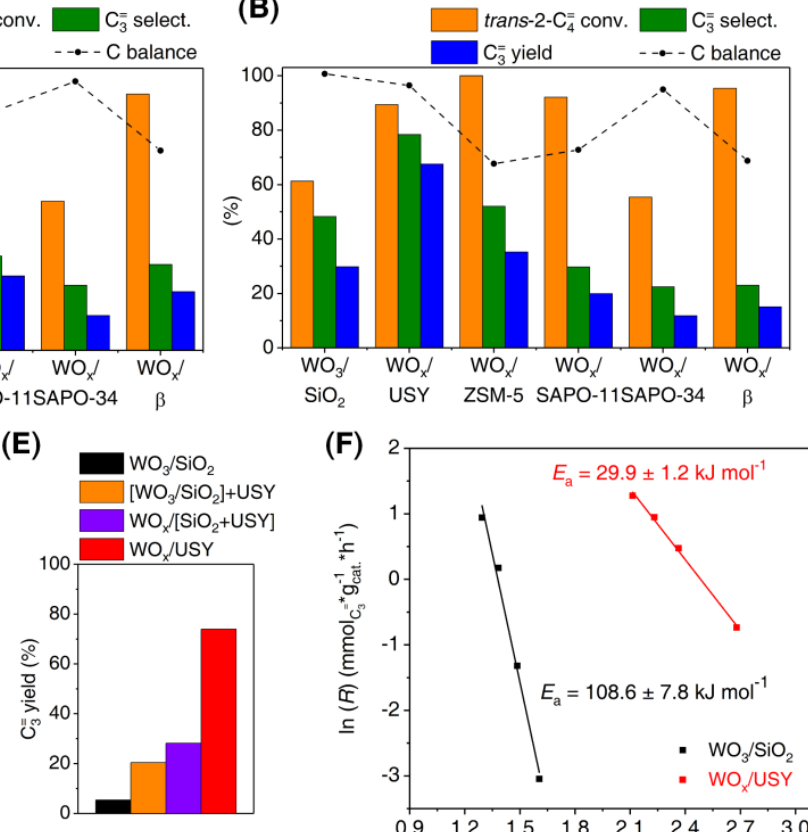

(F)

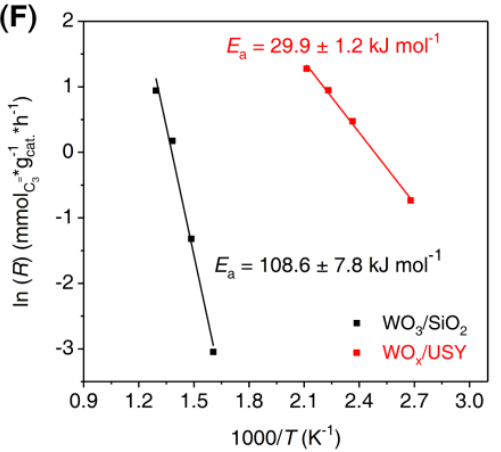

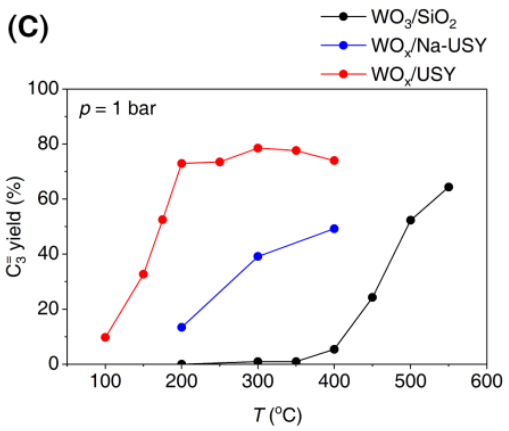

(G)

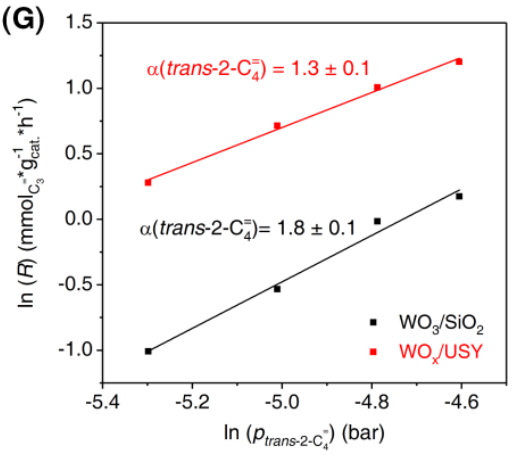

Figure 1. Catalytic activities of $\mathbf{W O}_{\mathbf{x}} /$ zeolite catalysts. (A) Trans-2-butene conversion, propene selectivity, propene yield and carbon balance over $\mathrm{WO}_{\mathrm{x}} /$ zeolite catalysts compared to those over $\mathrm{WO}_{3} / \mathrm{SiO}_{2}$ at $T=400^{\circ} \mathrm{C}, p=1$ and (B) 20 bar. Time on steam $(\mathrm{TOS})=1 \mathrm{~h}$. (C) Propene yield over $\mathrm{WO}_{3} / \mathrm{SiO}_{2}, \mathrm{WO}_{\mathrm{x}} / \mathrm{USY}$ and $\mathrm{WO}_{\mathrm{x}} / \mathrm{Na}-\mathrm{USY}$ at $T=100-550^{\circ} \mathrm{C}, p=1$ bar and $(\mathbf{D})$ at $T=400^{\circ} \mathrm{C}, p=$ 1 and 20 bar. TOS $=0.25 \mathrm{~h}$. Carbon balance is above $95 \%$ in all experiments. (E) Propene yield over $\mathrm{WO}_{3} / \mathrm{SiO}_{2},\left[\mathrm{WO}_{3} / \mathrm{SiO}_{2}\right]+\mathrm{USY}_{\text {, }}$ $\mathrm{WO}_{\mathrm{x}} /\left[\mathrm{SiO}_{2}+\mathrm{USY}\right]$ and $\mathrm{WO}_{\mathrm{x}} / \mathrm{USY}$ at $T=400^{\circ} \mathrm{C}, p=1$ bar. $\mathrm{SiO}_{2}$ to USY mass ratio $=19 / 1$. TOS $=1 \mathrm{~h}$. Carbon balance is above $95^{\%}$ in all experiments. (F) Arrhenius plots for $\mathrm{WO}_{3} / \mathrm{SiO}_{2}$ and $\mathrm{WO}_{\mathrm{x}} / \mathrm{USY}$ at $T=100-500^{\circ} \mathrm{C}, p=1$ bar. (G) Dependencies of propene production rate on the partial pressure of trans-2-butene over $\mathrm{WO}_{3} / \mathrm{SiO}_{2}$ and $\mathrm{WO}_{\mathrm{x}} / \mathrm{USY}$ at $T=450^{\circ} \mathrm{C}, p=1$ bar. $\alpha$ : order of reaction.

SXRD. High-resolution SXRD data were collected at beamline In, Diamond Light Source, UK. The energy of the incident X-ray was $15 \mathrm{keV}$. The wavelength and the $2 \theta$ zero point were determined by fitting the diffraction data of high-quality silicon powder (SRM640c). SXRD data were collected for a $\mathrm{WO}_{\mathrm{x}} / \mathrm{USY}$ sample, a $\mathrm{WO}_{\mathrm{x}} / \mathrm{ZSM}-5$ sample, a $\mathrm{WO}_{\mathrm{x}} / \mathrm{Na}$-USY sample, and a trans-2-buteneadsorbed $\mathrm{WO}_{\mathrm{x}} / \mathrm{USY}\left(\mathrm{t} 2 \mathrm{be}-\mathrm{WO}_{\mathrm{x}} / \mathrm{USY}\right.$ ) sample. Before data collection, $\mathrm{WO}_{\mathrm{x}} / \mathrm{USY}$ and $\mathrm{WO}_{\mathrm{x}} / \mathrm{ZSM}-5$ was treated under vacuum at $300^{\circ} \mathrm{C}$ for $2 \mathrm{~h}$. Adsorbed water should have been removed completely. The adsorption of trans-2butene $\left(2 \%\right.$ in $\left.\mathrm{N}_{2}\right)$ on $\mathrm{WO}_{\mathrm{x}} /$ USY was performed at room temperature using a Schlenk line. The sample was treated under vacuum at $300^{\circ} \mathrm{C}$ for $2 \mathrm{~h}$ beforehand. Adsorbed water should have been removed completely. Liquid $\mathrm{N}_{2}$ was used to quench the adsorption of trans-2-butene.

All samples were loaded into borosilicate glass capillaries (0.7 mm inner diameter) in a glove box. Glass wool was packed on top of the sample. SXRD data were collected in a Debye-Scherrer geometry using multi-analyzer crystals (MAC) detectors in the $2 \theta$ range of $0-150^{\circ}$ with $0.001^{\circ}$ data binning. Each data set was collected for $1 \mathrm{~h}$ for good statistics.

DFT calculation. All periodic calculations were performed using spin-polarized DFT within the generalized gradient approximation (GGA) as implemented in the Vienna ab initio simulation package (VASP). ${ }^{14-16}$ The core and valence electrons were represented by the plane-wave basis set using the projector augmented wave (PAW) method $^{17,18}$ with a kinetic cutoff energy of $500 \mathrm{eV}$. The exchange-correlation functional was the Perdew-BurkeErnzerhof (PBE) functional. ${ }^{19}$ Brillouin zone sampling was restricted to $\Gamma$ point. The energy and force convergence criteria were $1.0 \times 10^{-6} \mathrm{eV}$ and $0.02 \mathrm{eV} \cdot \AA^{-1}$ in all structure optimizations. The van der Waals dispersion interaction between the adsorbate and the zeolite framework was included using DFT-D2 scheme. ${ }^{20}$ Transition states of elementary steps in the reaction pathways were located using the climbing image nudged elastic band (CI-NEB) method $^{21,22}$ and the dimer method ${ }^{23}$.

For BAS-catalyzed reaction, the confinement and steric hindrance strongly affect the stabilities of reaction intermediates and transition states. ${ }^{24}$ To account for important entropic contribution $(\Delta S)$ and zero-point vibrational energy ( $\triangle \mathrm{ZPVE})$ corrections, both Gibbs free energy $(\Delta \mathrm{G})$ and enthalpy $(\Delta \mathrm{H})$ changes along reaction pathways were calculated as follows: 25,26

$\Delta \mathrm{G}=\Delta \mathrm{H}-\mathrm{T} \Delta \mathrm{S}$

$\Delta \mathrm{H}=\Delta \mathrm{U}_{\text {trans }}+\Delta \mathrm{U}_{\text {rot }}+\Delta(\mathrm{ZPVE})+\Delta \mathrm{H}_{\text {elec }}$

$\Delta \mathrm{S}=\Delta \mathrm{S}_{\text {trans }}+\Delta \mathrm{S}_{\text {rot }}+\Delta \mathrm{S}_{\text {vib }}$

where translational, rotational, and vibrational contributions to internal energy $(\Delta \mathrm{U})$ and entropy $(\Delta \mathrm{S})$ were calculated using standard statistical thermodynamic method. ${ }^{27}$ The electronic term $\left(\Delta \mathrm{H}_{\text {elec }}\right)$ was derived from DFT calculation. The vibrational frequencies of the molecules of interest were calculated in the framework of harmonic oscillator approximation with a displacement of $0.01 \AA$. 
For the calculation of vibrational frequencies, only mobile reaction intermediates over $\mathrm{WO}_{4}$ MAS as well as first- and second-shell neighboring atoms at BAS were considered. All other atoms of USY framework were fixed. In the estimation of vibrational entropy contribution to Gibbs free energy, the spurious imaginary and low-lying vibrational frequencies $\left(<50 \mathrm{~cm}^{-1}\right)$ that were inevitably obtained in the vibrational frequency calculation were replaced by a normal mode of $50 \mathrm{~cm}^{-1}$. $28-30$

\section{RESULTS AND DISCUSSION}

Catalytic activities. Laboratory characterization results indicate that $\mathrm{WO}_{\mathrm{x}}$ MAS are well dispersed over all $\mathrm{WO}_{\mathrm{x}}$ /zeolite catalysts except for $\mathrm{WO}_{\mathrm{x}} / \mathrm{SAPO}-34$ (Figs. $\mathrm{S}_{1-4}$, Table $\mathrm{S}_{3}$ ). Figure $1 \mathrm{~A}$ shows that the catalytic activities of all $\mathrm{WO}_{\mathrm{x}} /$ zeolite catalysts are superior to that of $\mathrm{WO}_{3} / \mathrm{SiO}_{2}$ at 1 bar, which can be indicative of a synergy between $\mathrm{WO}_{\mathrm{x}} \mathrm{MAS}$ and the acidic sites in zeolites. Figure $1 \mathrm{~B}$ shows that the catalytic activity of $\mathrm{WO}_{3} / \mathrm{SiO}_{2}$ can be significantly improved at 20 bar. This could be due to the increased rate of olefin adsorption over $\mathrm{WO}_{\mathrm{x}}$ MAS under higher applied pressure. It is interesting that the catalytic properties of all $\mathrm{WO}_{\mathrm{x}}$ /zeolite catalysts remain similar at the two different applied pressures, indicating that olefin adsorption could have readily taken place at a lower pressure in the presence of acidic sites. The difference in the catalyst acidity and zeolite structure can be seen as the primary cause of the variation in the catalytic activities of $\mathrm{WO}_{\mathrm{x}} /$ zeolite catalysts. $\mathrm{WO}_{\mathrm{x}} / \mathrm{ZSM}-5, \mathrm{WO}_{\mathrm{x}} / \mathrm{SAPO}-11$ and $\mathrm{WO}_{\mathrm{x}} / \beta$ with high acidic strength and/or large acid quantity (Fig. S5) can give high trans-2-butene conversions but low propene selectivities and poor carbon balances. These materials favor the formation of heavy hydrocarbons and carbonaceous deposition due to their strong acidity and characteristic porous structures (Figs. S6-9). Less effective $\mathrm{WO}_{\mathrm{x}}$ dispersion is found in $\mathrm{WO}_{\mathrm{x}} / \mathrm{SAPO}-34$, as the smaller SAPO-34 pores inhibit the immigration of $\mathrm{WO}_{x}$ during synthesis. This accounts for the lower catalytic activity of $\mathrm{WO}_{\mathrm{x}} / \mathrm{SAPO}-34$.

Among all the catalysts studied, $\mathrm{WO}_{\mathrm{x}} / \mathrm{USY}$ exhibits the highest catalytic activity. As shown in Figs. $1 \mathrm{C}$ and $1 \mathrm{D}$, with $\mathrm{WO}_{3} / \mathrm{SiO}_{2}$ as a reference, $\mathrm{WO}_{\mathrm{x}} / \mathrm{USY}$ achieves significantly and consistently higher trans-2-butene conversions $(85-92 \%)$, propene selectivities $(78-88 \%)$ and propene yields $(70-79 \%)$ over a wide range of reaction conditions $\left(T=200-400^{\circ} \mathrm{C}, p=1-20 \mathrm{bar}\right)$. $\mathrm{WO}_{\mathrm{x}} / \mathrm{USY}$ also shows good stability for at least 20 hours in our academic laboratory (Fig. Sio). Under mild conditions $\left(T=200^{\circ} \mathrm{C}, p=1\right.$ bar), the propene production rate over $\mathrm{WO}_{\mathrm{x}} / \mathrm{USY} \quad(3.5$ $\left.\mathrm{mmol} \cdot \mathrm{g}_{\text {cat. }}{ }^{-1} \mathrm{~h}^{-1}\right)$ is $c a \cdot 7,300$ times that over the industrial $\mathrm{WO}_{3} / \mathrm{SiO}_{2}$ based catalyst $\left(4.8 \times 10^{-4} \mathrm{mmol} \cdot \mathrm{gcat}^{-1}{ }^{-1} \mathrm{~h}^{-1}\right)$ (See SI for rate calculation and number of active sites). We attribute this unprecedented high reaction rate over $\mathrm{WO}_{\mathrm{x}} /$ USY to the isolation of $\mathrm{WO}_{\mathrm{x}}$ MAS in zeolite pores and the placement of $\mathrm{WO}_{\mathrm{x}} \mathrm{MAS}$ in atomic proximity to BAS for highly efficient cooperative catalysis of olefin metathesis.
Isolated $\mathbf{W O}_{\mathbf{x}}$ MAS. The isolation of $\mathrm{WO}_{\mathrm{x}}$ MAS in USY pores was confirmed by high-resolution STEM. Isolated $\mathrm{W}$-containing species can be clearly identified in the HAADF-STEM image of $\mathrm{WO}_{\mathrm{x}} /$ USY (Figs. 2A, $2 \mathrm{~B}$ and S11). They appear to locate inside USY pores. USY framework underwent significant radiation damage during the image acquisition process due to the well-known electron beam sensitivity of zeolites. ${ }^{11,32}$ Thus it is acceptable that part of the $\mathrm{W}$-containing species aggregated and formed small clusters on the particle surface with increased electron beam exposure and consequent damage. Isolated $\mathrm{WO}_{\mathrm{x}}$ MAS was subsequently revealed to be a discrete molecular dioxo tungstate $(\mathrm{O}=)_{2} \mathrm{~W}(-\mathrm{O})_{2}\left(\mathrm{WO}_{4}\right.$ MAS) by the best fitting of the $k^{3}$-weighted $\mathrm{W} \mathrm{L}_{3}$-edge EXAFS spectra of $\mathrm{WO}_{\mathrm{x}} /$ USY (Figs. $2 \mathrm{C}, \mathrm{S} 12$ and $\mathrm{S}_{13}$, Tables 1 and $\mathrm{S}_{4}$ ).

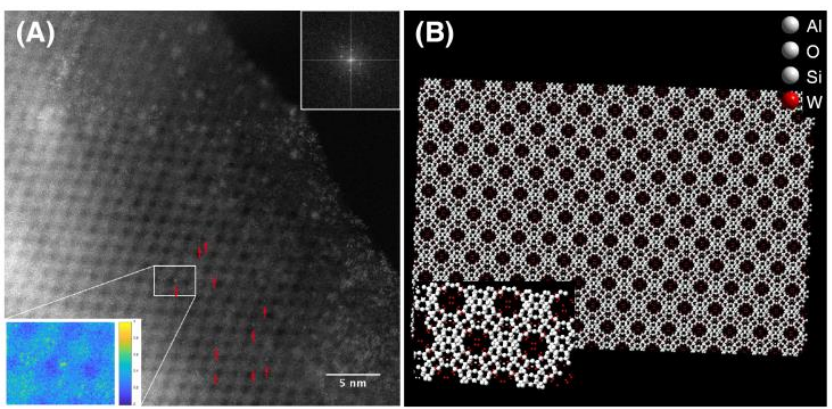

(C)
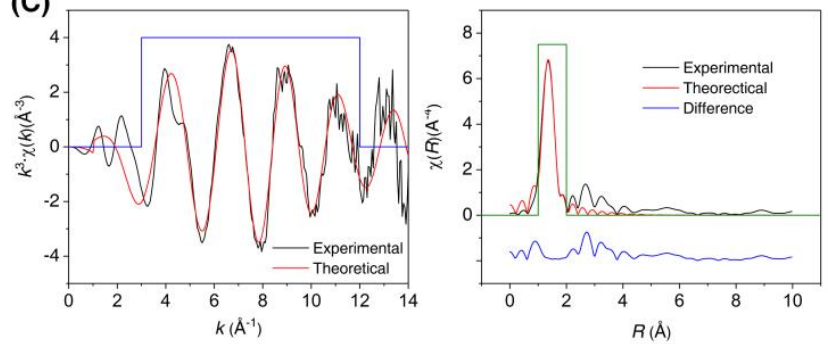

Figure 2. Isolated $\mathbf{W O}_{\mathbf{x}}$ MAS. (A) HAADF-STEM image of

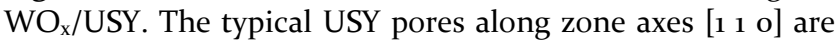
shown to be filled with atomic W-containing species (red arrows). The lower left inset shows an enlarged area where the W-containing species is clearly visible. (B) Crystallographic model of $\mathrm{WO}_{\mathrm{x}} / \mathrm{USY}$ from Rietveld refinement (also see Figure 3). The locations of $\mathrm{W}$ are in good agreement with those found in the STEM image. (C) $k^{3}$-weighted $\mathrm{W} \mathrm{L}_{3}$-edge EXAFS spectra of $\mathrm{WO}_{\mathrm{x}} / \mathrm{USY}$. $k$-range for fitting is $3^{-12} \AA^{-1} \cdot R$ range for fitting is $1-2 \AA$.

Table 1. Structural data for $\mathrm{WO}_{\mathrm{x}}$ MAS in $\mathrm{WO}_{\mathrm{x}} /$ USY from

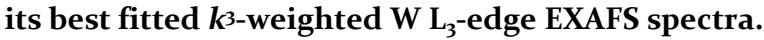

\begin{tabular}{llll}
\hline Scattering path & \multicolumn{2}{l}{$R=0.3 \%, E_{\text {not }}=4.1$} & \\
\hline & $\begin{array}{l}\text { Bond } \\
\text { length }(\AA)\end{array}$ & $\begin{array}{l}\text { Coordination } \\
\text { number }\end{array}$ & $\begin{array}{l}\text { Debye- } \\
\text { Waller } \\
\text { factor }\end{array}$ \\
$\mathrm{W}-\mathrm{O}_{1}$ & $1.75(1)$ & $2.2(1)$ & $0.003(1)$ \\
$\mathrm{W}-\mathrm{O}_{2}$ & $1.90(2)$ & $0.8(1)$ & $0.003(2)$ \\
$\mathrm{W}-\mathrm{O}_{3}$ & $2.12(1)$ & $1.1(2)$ & $0.006(2)$ \\
\hline
\end{tabular}

It is anticipated that $\mathrm{WO}_{4}$ MAS inside USY pores may interact with BAS nearby. This is illustrated by comparing the catalytic activities of $\mathrm{WO}_{\mathrm{x}} / \mathrm{USY}$ and $\mathrm{WO}_{\mathrm{x}} / \mathrm{Na}-\mathrm{USY}$ 
(Figs. ${ }_{1} \mathrm{C}$ and $\left.{ }_{1} \mathrm{D}\right)$. In the absence of $\mathrm{BAS}\left(\mathrm{H}^{+}\right.$replaced by $\mathrm{Na}^{+}$), $\mathrm{WO}_{\mathrm{x}} / \mathrm{Na}$-USY clearly delivers inferior catalytic activity to $\mathrm{WO}_{\mathrm{x}} / \mathrm{USY}$ despite its catalytic activity is still superior to that of $\mathrm{WO}_{3} / \mathrm{SiO}_{2}$. This supports our hypothesis that BAS in zeolite work in synergy with $\mathrm{WO}_{4}$ MAS to enhance the overall catalytic activity. As shown in Fig. $1 \mathrm{E}$, the catalytic activity of our bifunctional catalyst is critically dependent on the interface between $\mathrm{WO}_{4} \mathrm{MAS}$ and BAS. The physical mixture of $\mathrm{WO}_{3} / \mathrm{SiO}_{2}$ and USY $\left(\left[\mathrm{WO}_{3} / \mathrm{SiO}_{2}\right]_{+}\right.$ USY) and the $\mathrm{WO}_{\mathrm{x}}$-deposited mixture of $\mathrm{SiO}_{2}$ and USY $\left(\mathrm{WO}_{\mathrm{x}} /\left[\mathrm{SiO}_{2}+\mathrm{USY}\right]\right)$ have an ill-defined interface between $\mathrm{WO}_{4}$ MAS and BAS. Thus, they are far less active than $\mathrm{WO}_{\mathrm{x}} / \mathrm{USY}$ in the cross-metathesis of ethene and trans-2butene to propene. The high catalytic activity of $\mathrm{WO}_{\mathrm{x}} / \mathrm{USY}$ appears to be due to the effective interaction(s) between $\mathrm{WO}_{4}$ MAS and BAS inside zeolite.

$\mathrm{WO}_{4}$ MAS and BAS in atomic proximity. To confirm that $\mathrm{WO}_{4}$ MAS and BAS are in atomic proximity in USY pores for high catalytic activity, SXRD combined with Rietveld refinement was employed to elucidate the spatial relationships between $\mathrm{WO}_{4}$ MAS and BAS in $\mathrm{WO}_{\mathrm{x}} / \mathrm{USY}$. It is difficult to visualize local 3-dimensional atomic interaction(s) by traditional spectroscopic techniques, e.g. UVVis, Raman, infrared, electron paramagnetic resonance and X-ray absorption spectroscopy, which are commonly used for olefin metathesis catalyst characterization.,31,33,34 This information is also essential when developing an understanding of the cooperative catalysis within a confined zeolite cavity. ${ }^{35-37}$

The structural details of unmodified USY along with the strength, quantity, and location of BAS have been reported in our previous work. ${ }^{38}$ BAS $\left(\mathrm{H}^{+}\right)$locates on $\mathrm{O}_{4}$ of USY framework with various strength. We determined the location of $\mathrm{WO}_{4}$ MAS in USY by refining the crystal structure of $\mathrm{WO}_{\mathrm{x}} / \mathrm{USY}$ using Rietveld method in TOPASAcademic $5^{39}$ based on its high-resolution SXRD data. See SI for general Rietveld refinement procedure. The rigid bodies describing $\mathrm{WO}_{4}$ MAS were built based on EXAFS results and were added into USY framework one by one, following the indication from difference Fourier map. Weighted-profile $R$-factor $\left(R_{\mathrm{wp}}\right)$ and goodness-of-fit (GOF) were used to gauge the quality of Rietveld refinement. After the first $\mathrm{WO}_{4}$ rigid body was added, $R_{\mathrm{wp}}$ and GOF were found to decrease, indicating the addition of $\mathrm{WO}_{4}$ rigid body was appropriate. The site occupancy of the second $\mathrm{WO}_{4}$ rigid body added turned to be almost zero. Thus, the existence of the second $\mathrm{WO}_{4}$ rigid body was not considered. As a result, one $\mathrm{WO}_{4}$ rigid body was used to fit the SXRD data (Figs. $3 \mathrm{~A}$ and $\mathrm{S}_{14}$ ). The resulting crystallographic model of $\mathrm{WO}_{\mathrm{x}} / \mathrm{USY}$ (Fig. $2 \mathrm{~B}$ ) matches with its STEM images (Figs. 2A and S11).

It is shown that the isolated $\mathrm{WO}_{4}$ MAS is trapped in USY cavity by $\mathrm{W}-\mathrm{O} \cdots(\mathrm{H}) \mathrm{O}_{4}$ hydrogen bonding

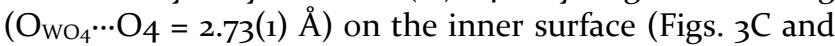
$3 \mathrm{D})$. DFT calculation indicates the interaction energy between $\mathrm{WO}_{4}$ MAS and $(\mathrm{H}) \mathrm{O}_{4}$ (BAS) is $-141 \mathrm{~kJ} \cdot \mathrm{mol}^{-1}$ (See DFT calculation section and SI for details). The BAS directly bound to $\mathrm{WO}_{4}$ MAS has been demonstrated to be reinforced by the extra-framework $\mathrm{Al}^{3+}$ (EFAl) in the soda- lite cage due to the polarization effect of EFAl on $\mathrm{O}_{4} \cdot{ }^{38}$ These strong BAS (sBAS) are fully taken up by $\mathrm{WO}_{4} \mathrm{MAS}$ for immobilization according to their resolved site occupancies (sBAS: 2.1 per unit cell (u.c.), $\mathrm{WO}_{4}$ MAS: 2.8 per u.c.). There are remaining weak BAS (wBAS: 5.1 per u.c.) in close proximity to the immobilized $\mathrm{WO}_{4}$ MAS in USY cavity. The unoccupied wBAS in $\mathrm{WO}_{\mathrm{x}} / \mathrm{USY}$ can be selectively replaced by $\mathrm{Na}^{+}$. This is confirmed by the crystallographic position and resolved site occupancy (5.0 per u.c.) of $\mathrm{Na}^{+}$in $\mathrm{WO}_{\mathrm{x}} / \mathrm{Na}$-USY (Fig. $3 \mathrm{E}$, see SI for detailed Rietveld refinement procedure and Fig. $S_{15}$ for data fitting). As described previously, the inhibition of wBAS results in a dramatic decrease in catalytic activity. This reflects the important role of unoccupied BAS in atomic proximity to $\mathrm{WO}_{4} \mathrm{MAS}$ for enhanced reaction rates.
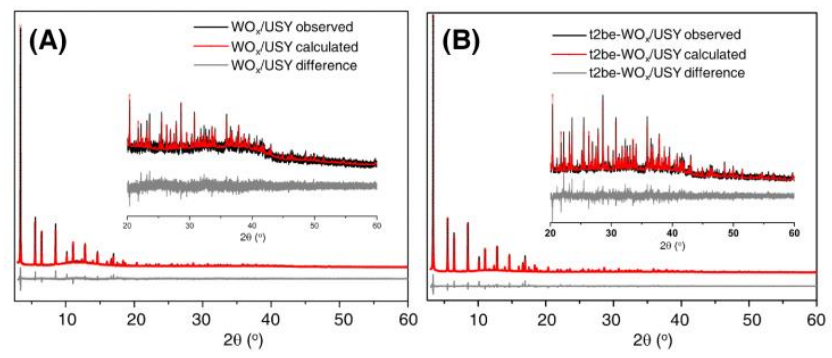

(C)

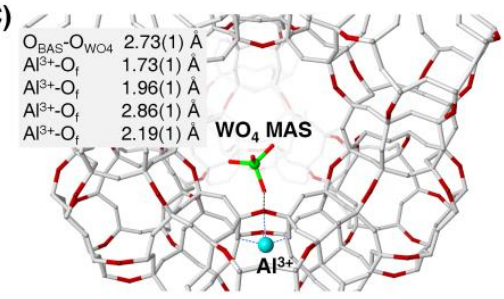

(D)
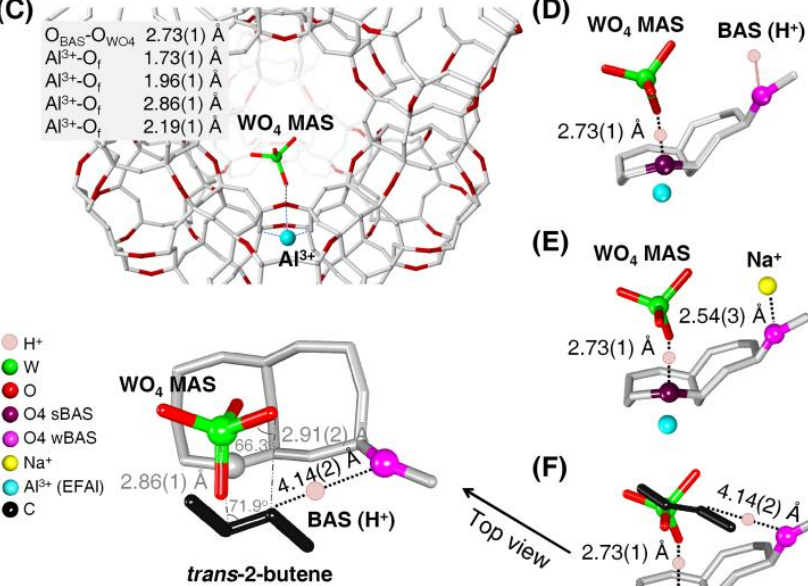

(E)
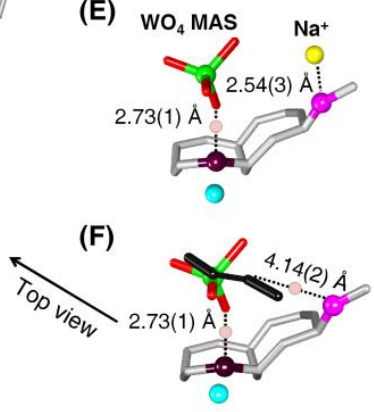

Figure 3. Structure of $\mathrm{WO}_{\mathrm{x}} /$ USY. SXRD data of (A) $\mathrm{WO}_{\mathrm{x}} / \mathrm{USY}$ and (B) trans-2-butene-adsorbed $\mathrm{WO}_{\mathrm{x}} / \mathrm{USY}$, fitted by Rietveld refinement. Data in the $2 \theta$ range of $20-60^{\circ}$ are zoomed in to illustrate the quality of Rietveld refinement. (C) Crystallographic model of $\mathrm{WO}_{\mathrm{x}} /$ USY from Rietveld refinement. Although $\mathrm{H}$ is invisible in SXRD, $\mathrm{O}_{4}$ of USY, where BAS $\left(\mathrm{H}^{+}\right)$locate, are shown in red. (D) $\mathrm{WO}_{4}$ MAS immobilized through hydrogen bonding to ( $\mathrm{H}_{4} \mathrm{O}_{4}$ of USY. Dummy $\mathrm{H}^{+}$is added for illustration. (E) The crystallographic position of $\mathrm{Na}^{+}$in $\mathrm{WO}_{\mathrm{x}} / \mathrm{Na}$-USY (replacing $\mathrm{H}^{+}$). (F) Trans-2-butene adsorbed on $\mathrm{WO}_{\mathrm{x}} / \mathrm{USY}$ showing significant interaction(s) between its double bond, unoccupied $\mathrm{BAS}$, and $\mathrm{W}=\mathrm{O}$ of $\mathrm{WO}_{4}$ MAS to form the stereospecific adsorption geometry shown.

We also found a similar entrapment and site isolation of $\mathrm{WO}_{4}$ MAS in $\mathrm{WO}_{\mathrm{x}} / \mathrm{ZSM}-5$ (see SI for detailed explanation, Figs. S16-18 and Table S5) and unoccupied BAS were also shown to be present. We expect that acid quantity, distribution, and strength will significantly affect the ad- 
sorption kinetics of olefin molecules, hence influencing the overall olefin metathesis rate over nearby $\mathrm{WO}_{4} \mathrm{MAS}$. Strong unoccupied BAS in zeolites with stereospecific arrangements may also catalyze side reactions such as isomerization, undesirable cracking, heavy hydrocarbon formation and/or carbon deposition, leading to poor propene selectivity and rapid catalyst deactivation, as in the case of $\mathrm{WO}_{\mathrm{x}} / \mathrm{ZSM}-5$. The weak unoccupied BAS in $\mathrm{WO}_{\mathrm{x}} / \mathrm{USY}$ guarantees high olefin metathesis catalytic activity and stability of the catalyst without significant side products and extensive carbon formation. In addition, the weak unoccupied BAS in $\mathrm{WO}_{\mathrm{x}} /$ USY appear to be capable of catalyzing 1-butene (present in industrial reformate gases) to form 2-butene which participates in the cross-metathesis reaction with ethene to form propene. As a result, $c a$. $55 \%$ propene yield with $c a$. $95 \%$ 1-butene conversion can be achieved over $\mathrm{WO}_{\mathrm{x}} / \mathrm{USY}$ at $400^{\circ} \mathrm{C}$ and 1 bar. This reflects the highly cooperative adsorption-metathesis mechanism in this well-designed catalyst.

Cooperative catalysis over the BAS-MAS pair. Effective cooperative catalysis over the BAS-MAS pair is envisaged to be due to the appropriate alignment between the $\mathrm{C}=\mathrm{C}$ bond of olefin molecules adsorbed over BAS and the $\mathrm{W}=\mathrm{O}$ bond of $\mathrm{WO}_{4}$ MAS. To confirm this hypothesis, trans-2-butene was loaded in $\mathrm{WO}_{4} / \mathrm{USY}$ for the study of its adsorption geometry by SXRD and Rietveld refinement (Fig. 3B, see SI for detailed Rietveld refinement procedure and Fig. S19 for data fitting). The trans-2-butene molecule was found to be adsorbed over the unoccupied BAS with an $\mathrm{O}_{4}(\mathrm{H}) \cdots \mathrm{C}^{=}{ }_{\text {tzbe }}$ distance of 4.14(2) $\AA$ (t2be: trans-2-butene) (Fig. $3 \mathrm{~F}$ ). This distance is expected for a significant interaction between the electron-rich $\mathrm{C}=\mathrm{C}$ bond of trans-2-butene and the unoccupied BAS $\left(\mathrm{H}^{+}\right)$. This could easily lead to the protonation of trans-2-butene at elevated temperature. ${ }^{40}$

Perhaps, the most intriguing observation is that the $\mathrm{C}=\mathrm{C}$ bond of trans-2-butene appears to have aligned with the $\mathrm{W}=\mathrm{O}$ bond of nearby $\mathrm{WO}_{4}$ MAS at room temperature

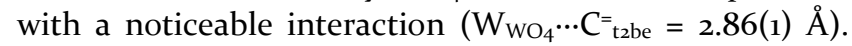
The $\mathrm{C}=\mathrm{C}$ bond of trans-2-butene and the $\mathrm{W}=\mathrm{O}$ bond of $\mathrm{WO}_{4}$ MAS show a distorted square arrangement, which resembles the anticipated oxametallocycle intermediate formed in the initiation step (Pseudo-Wittig initiation mechanism, Scheme 1). The oxametallocycle intermediate will lead to the formation of a reactive $\mathrm{W}$ carbene $\left(\mathrm{W}=\mathrm{CHCH}_{3}\right)$ to start the metallacyclobutane catalytic cycle for catalytic olefin metathesis (Chauvin reaction mechanism, Scheme 1). In the metallacyclobutane catalytic cycle, it is envisaged that BAS facilitates the adsorption and alignment of ethene to the nearby $\mathrm{W}$ carbene with stereospecificity in a similar manner to form a metallocyclobutane intermediate before propene is produced.

DFT calculation. DFT calculation was carried out to study the metallacyclobutane catalytic cycle. USY model $\left(\mathrm{T}_{192} \mathrm{O}_{384}, \mathrm{~T}=\mathrm{Si}\right.$ or $\left.\mathrm{Al}\right)$ was built based on our previous work..$^{8}$ It has a lattice parameter of 24.2680 Å and 7 BAS. $9 \mathrm{Si}^{4+}$ at specific framework $\mathrm{T}$ sites were replaced by $\mathrm{Al}^{3+}$ and 2 extra-framework $\mathrm{Al}^{3+}$ were added in the sodalite cage. The resulting negatively charged USY framework was compensated by adding $7 \mathrm{H}^{+}$at the $\mathrm{O}^{2-}$ directly connected to $\mathrm{Al}^{3+}$ (framework) and adding $2\left[(\mathrm{O}=)_{2} \mathrm{~W}(-\mathrm{O})_{2}\right]^{2-}$ $\left(\mathrm{WO}_{4} \mathrm{MAS}\right)$ at random positions. These added $\mathrm{H}^{+}$are active BAS of USY. Structure optimization shows that $\mathrm{WO}_{4}$ MAS inside USY are most likely bound to $\mathrm{H}-\mathrm{O}_{4}$ of the framework (Fig. S2O). This is in line with the results from Rietveld refinement.

We first calculated the adsorption and conversion of ethene and trans-2-butene over $\mathrm{WO}_{4} \mathrm{MAS}$, in order to determine which of the two, $\mathrm{W}=\mathrm{CH}_{2}$ and $\mathrm{W}=\mathrm{CHCH}_{3}$, is the intermediate to initiate the metallacyclobutane catalytic cycle. As shown in Fig. S21, the formation of the $\mathrm{W}=\mathrm{CHCH}_{3}$ from trans-2-butene is thermodynamically more favored due to its lower Gibbs reaction energies. In particular, the formation of $\mathrm{W}=\mathrm{CHCH}_{3}$ in the presence of an unoccupied neighboring BAS is kinetically feasible. Therefore $\mathrm{W}=\mathrm{CHCH}_{3}$ with unoccupied BAS nearby was used as the intermediate to initiate the metallacyclobutane catalytic cycle.

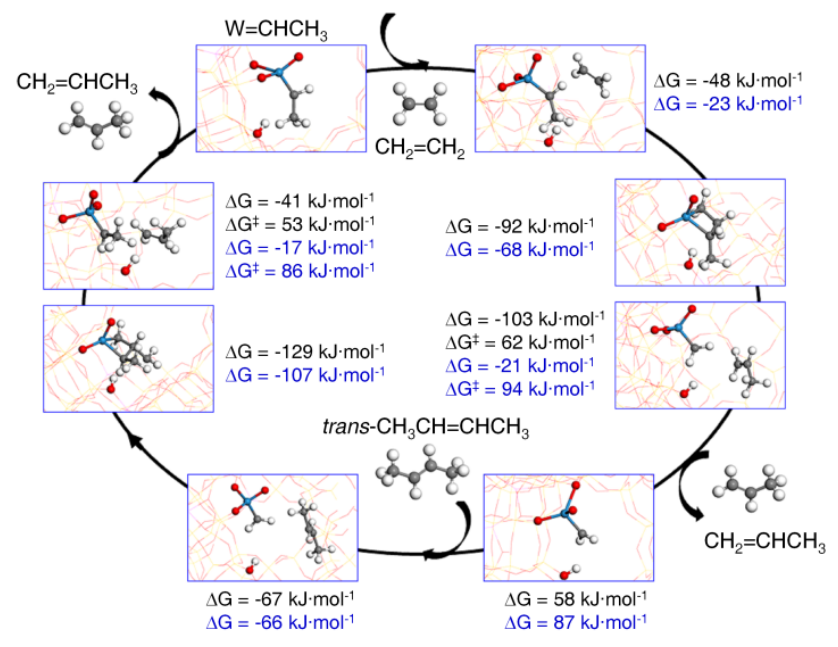

Figure 4. Energy diagram of the metallacyclobutane catalytic cycle over $\mathrm{W}$ carbene $\left(\mathrm{W}=\mathrm{CHCH}_{3}\right)$ in $\mathrm{WO}_{\mathbf{x}} / \mathrm{USY}$. Numbers in black and blue are DFT calculated Gibbs free energies in the presence and absence of an unoccupied BAS near $\mathrm{W}=\mathrm{CHCH}_{3}$, respectively. The optimized structures in the presence of an unoccupied neighboring BAS are shown.

Figure 4 shows the energy diagram of the metallacyclobutane catalytic cycle over $\mathrm{W}=\mathrm{CHCH}_{3}$ in the presence/absence of an unoccupied BAS nearby. The metallacyclobutane catalytic cycle is initialized by ethene being adsorbed at $\mathrm{W}=\mathrm{CHCH}_{3}$ to form a W cyclobutane intermediate. This is followed by the concerted $\mathrm{C}-\mathrm{C}$ and $\mathrm{W}-\mathrm{C}$ bond scissions leading to the formation of the first propene. This step is exothermic with a reaction energy $(\Delta \mathrm{G})$ of $-21 \mathrm{~kJ} \cdot \mathrm{mol}^{-1}$ in the absence of BAS. The calculated Gibbs energy of activation $\left(\Delta \mathrm{G}^{\ddagger}\right)$ is $94 \mathrm{~kJ} \cdot \mathrm{mol}^{-1}$. This is comparable to the experimental apparent activation energy $\left(E_{\mathrm{a}}\right)$ obtained for $\mathrm{WO}_{3} / \mathrm{SiO}_{2}$ which does not have BAS close to its MAS (108.6 kJ.mol ${ }^{-1}$, Fig. $\left.1 \mathrm{~F}\right)$. This kinetically relevant step in the first half of the metallacyclobutane catalytic cycle is significantly promoted when an unoccu- 
pied neighboring BAS is present. A dramatically low $\Delta G^{\ddagger}$ $\left(62 \mathrm{~kJ} \cdot \mathrm{mol}^{-1}\right)$ was obtained and the concerted $\mathrm{C}-\mathrm{C}$ and $\mathrm{W}-\mathrm{C}$ bond scissions are more exothermic $(\Delta \mathrm{G}=-103$ $\left.\mathrm{kJ} \cdot \mathrm{mol}^{-1}\right)$. The cooperation between the active $\mathrm{W}=\mathrm{CHCH}_{3}$ and the unoccupied neighboring BAS is shown to play a key role in increasing olefin metathesis reaction rate, despite that the experimental $E_{\mathrm{a}}$ for $\mathrm{WO}_{\mathrm{x}} / \mathrm{USY}\left(29.9 \mathrm{~kJ} \cdot \mathrm{mol}^{-1}\right.$, Fig. $1 \mathrm{~F}$ ) cannot allow a direct comparison with the activation barrier obtained from DFT calculation. The value of experimental $E_{\mathrm{a}}$ is indicative of diffusion limitation which leads to a complex rate-temperature relationship..$^{41}$ Upon releasing the first propene, a reactive $\mathrm{W}=\mathrm{CH}_{2}$ is formed and is ready for the adsorption of trans-2-butene to form a W cyclobutane intermediate subsequently. It is found that the adsorption of trans-2-butene and the formation of the $\mathrm{W}$ cyclobutane intermediate are affected by the presence of the unoccupied neighboring BAS. More importantly, the calculated $\Delta G^{\ddagger}$ of the second concerted $C-C$ and $\mathrm{W}-\mathrm{C}$ bond scissions in the presence of the unoccupied neighboring BAS $\left(53 \mathrm{~kJ} \cdot \mathrm{mol}^{-1}\right)$ is much lower than that without BAS present $\left(86 \mathrm{~kJ} \cdot \mathrm{mol}^{-1}\right)$.

The order of reaction with respect to trans-2-butene in excessive ethene was evaluated for $\mathrm{WO}_{3} / \mathrm{SiO}_{2}(1.8 \pm 0.1)$ and $\mathrm{WO}_{\mathrm{x}} /$ USY $(1.3 \pm 0.1)$, respectively (Fig. $\left.1 \mathrm{G}\right)$. The apparent higher order of reaction with respect to trans-2butene in the case of $\mathrm{WO}_{3} / \mathrm{SiO}_{2}$ again suggests $\mathrm{WO}_{3} / \mathrm{SiO}_{2}$ has a stronger dependence on the availability of adsorbed olefin. This reflects the higher activation energy process of surface trans-2-butene adsorption is rather difficult to proceed in $\mathrm{WO}_{3} / \mathrm{SiO}_{2}$. In contrast, as demonstrated, the presence of unoccupied BAS in USY makes a significant contribution to increasing the availability of trans-2butene (with a lower $E_{\mathrm{a}}$ and a lower order of reaction, Fig. ${ }_{1} \mathrm{~F}$ and Fig. ${ }_{1} \mathrm{G}$ ) and ethene to $\mathrm{WO}_{4}$ MAS in the atomic vicinity. Thus both experimental and theoretical evaluations suggest that the cooperative catalysis between BAS and MAS lead to an overall enhanced catalytic activity.

\section{CONCLUSIONS}

We have designed a new type of bifunctional olefin metathesis catalysts by immobilizing isolated single $\mathrm{WO}_{4}$ MAS in a zeolite cavity where unoccupied BAS are in atomic proximity. Within the confined zeolite cavity, we demonstrate that BAS facilitate the adsorption and activation of olefin molecules for the metathesis reaction over $\mathrm{WO}_{4}$ MAS. This leads to a dramatically enhanced olefin metathesis reaction rate. We report exceptional propene production rate and thermal stability of $\mathrm{WO}_{\mathrm{x}} / \mathrm{USY}$ under industrially applicable conditions. In general, the concept of cooperative catalysis presented here, using two active sites of different functionalities within atomic proximity in a molecular cavity, can provide new opportunities for designing synergistically adsorptive and catalytic materials.

\section{ASSOCIATED CONTENT}

Supporting Information. Methods and additional results of catalyst testing, structure refinement, physical characteriza- tion, and suggested future work supplied as Supporting Information. This material is available free of charge via the Internet at http://pubs.acs.org.

\section{AUTHOR INFORMATION}

\section{Corresponding Author}

*edman.tsang@chem.ox.ac.uk

\section{Author Contributions}

† contributed equally as co-first author.

\section{Present Addresses}

\$College of Chemical Engineering, Beijing University of Chemical Technology, China.

\section{ACKNOWLEDGMENT}

The STEM, EXAFS and SXRD facilities provided by Diamond Light Source (UK) are acknowledged.

\section{REFERENCES}

(1) Lwin, S.; Wachs, I. E., ACS Catal. 2014, 4 (8), 2505-2520.

(2) Mol, J. C., J. Mol. Catal. A: Chem. 2004, 213 (1), 39-45.

(3) Lwin, S.; Li, Y.; Frenkel, A. I.; Wachs, I. E., ACS Catal. 2016, 6 (5), 3061-3071.

(4) Copéret, C.; Comas-Vives, A.; Conley, M. P.; Estes, D. P.; Fedorov, A.; Mougel, V.; Nagae, H.; Núñez-Zarur, F.; Zhizhko, P. A., Chem. Rev. 2016, 116 (2), 323-421.

(5) Mazoyer, E.; Szeto, K. C.; Merle, N.; Norsic, S.; Boyron, O.; Basset, J.-M.; Taoufik, M.; Nicholas, C. P., J. Catal. 2013, 301, 1-7.

(6) Balcar, H.; Čejka, J., Coord. Chem. Rev. 2013, 257 (21-22), 3107-3124.

(7) Grubbs, R. H.; Wenzel, A. G.; O'Leary, D. J.; Khosravi, E. Handbook of Metathesis, Wiley-VCH, Weinheim, 2015.

(8) Hérisson, J.-L.; Chauvin, Y., Makromol. Chem. 1971, 141 (1), 161-176.

(9) Cheng, Z.; Lo, C. S., ACS Catal. 2015, 5 (1), 59-72.

(10) Cheng, Z.; Lo, C. S., ACS Catal. 2012, 2 (3), 341-349.

(11) Amakawa, K.; Wrabetz, S.; Kröhnert, J.; Tzolova-Müller, G.; Schlögl, R.; Trunschke, A., J. Am. Chem. Soc. 2012, 134 (28), 11462-11473.

(12) Huang, S.; Liu, S.; Xin, W.; Bai, J.; Xie, S.; Wang, Q.; Xu, L., J. Mol. Catal. A: Chem. 2005, 226 (1), 61-68.

(13) Li, X.; Zhang, W.; Liu, S.; Xu, L.; Han, X.; Bao, X., J. Catal. 2007, 250 (1), 55-66.

(14) Kresse, G.; Furthmuller, J., Comput. Mater. Sci. 1996, 6 (1), 15-50.

(15) Kresse, G.; Furthmuller, J., Phys. Rev. B 1996, 54 (16), 1116911186.

(16) Kresse, G.; Hafner, J., Phys. Rev. B 1994, 49 (20), 1425114269.

(17) Blochl, P. E., Phys. Rev. B 1994, 50 (24), 17953-17979.

(18) Kresse, G.; Joubert, D., Phys. Rev. B 1999, 59 (3), 1758-1775.

(19) Perdew, J. P.; Chevary, J. A.; Vosko, S. H.; Jackson, K. A.; Pederson, M. R.; Singh, D. J.; Fiolhais, C., Phys. Rev. B 1992, 46 (11), 6671-6687.

(20) Grimme, S.; Antony, J.; Ehrlich, S.; Krieg, H., J. Chem. Phys. 2010, 132 (15), 154104.

(21) Henkelman, G.; Uberuaga, B. P.; Jonsson, H., J. Chem. Phys. 2000, 113 (22), 9901-9904.

(22) Mills, G.; Jonsson, H.; Schenter, G. K., Surf. Sci. 1995, 324 (2-3), 305-337.

(23) Henkelman, G.; Jónsson, H., J. Chem. Phys. 1999, 111 (15), 7010-7022. 35 . 
(24) Gounder, R.; Iglesia, E., Acc. Chem. Res. 2012, 45 (2), 229238.

(25) Mei, D.; Lercher, J. A., AIChE J. 2017, 63 (1), 172-184.

(26) Zhi, Y.; Shi, H.; Mu, L.; Liu, Y.; Mei, D.; Camaioni, D. M.; Lercher, J. A., J. Am. Chem. Soc. 2015, 137 (50), 15781-15794.

(27) Psofogiannakis, G.; St-Amant, A.; Ternan, M., J. Phys. Chem. B 2006, 110 (48), 24593-24605.

(28) Alexopoulos, K.; Lee, M. S.; Liu, Y.; Zhi, Y. C.; Liu, Y. S.; Reyniers, M. F.; Marin, G. B.; Glezakou, V. A.; Rousseau, R.; Lercher, J. A., J. Phys. Chem. C 2016, 120 (13), 7172-7182.

(29) Piccini, G.; Alessio, M.; Sauer, J.; Zhi, Y.; Liu, Y.; Kolvenbach, R.; Jentys, A.; Lercher, J. A., J. Phys. Chem. C 2015, 119 (11), 6128-6137.

(30) Piccini, G.; Sauer, J., J. Chem. Theory Comput. 2014, 10 (6), 2479-2487.

(31) Pan, M.; Crozier, P. A., Ultramicroscopy 1993, 48 (3), 332340.

(32) Terasaki, O.; Ohsuna, T.; Ohnishi, N.; Hiraga, K., Curr. Opin. Solid State Mater. Sci. 1997, 2 (1), 94-100.

(33) Ross-Medgaarden, E. I.; Wachs, I. E., J. Phys. Chem. C 2007, 111 (41), 15089-15099.

(34) Basrur, A. G.; Patwardhan, S. R.; Was, S. N., J. Catal. 1991, 127 (1), 86-95.

(35) Ye, L.; Song, Q.; Lo, B. T. W.; Zheng, J.; Kong, D.; Murray, C. A.; Tang, C. C.; Tsang, S. C. E., Angew. Chem. Int. Ed. 2017, 56 (36), 10711-10716.

(36) Teixeira, I. F.; Lo, B. T. W.; Kostetskyy, P.; Stamatakis, M.; Ye, L.; Tang, C. C.; Mpourmpakis, G.; Tsang, S. C. E., Angew. Chem. Int. Ed. 2016, 55 (42), 13061-13066.

(37) Lo, B. T. W.; Ye, L.; Qu, J.; Sun, J.; Zheng, J.; Kong, D.; Murray, C. A.; Tang, C. C.; Tsang, S. C. E., Angew. Chem. In. Ed. 2016, 55 (20), 5981-5984.

(38) Ye, L.; Teixeira, I.; Lo, B. T. W.; Zhao, P.; Tsang, S. C. E., Chem. Commun. 2017, 53 (70), 9725-9728.

(39) Coelho, A. A. TOPAS-Academic, 4.1; Coelho Software, Brisbane.: 2007.

(40) Nguyen, C. M.; De Moor, B. A.; Reyniers, M.-F.; Marin, G. B., J. Phys. Chem. C 2011, 115 (48), $23831-23847$.

(41) Bond, G. C., Heterogeneous Catalysis: Principles and Applications. 2nd ed.; Oxford University Presss: 1987. 
Table of Contents artwork

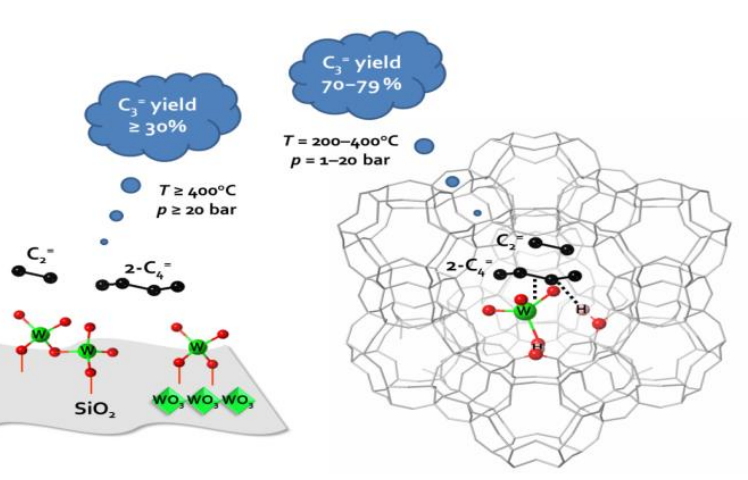

